\title{
When Education is Not the Solution: Public Policy in the Fight against Child Labor
}

\author{
Maria de Fatima Pereira Alberto ${ }^{1}$ \\ Department of Psychology, Graduate Program in Social Psychology, Universidade \\ Federal da Paraíba, João Pessoa, PB, Brazil \\ Oswaldo Hajime Yamamoto \\ Department of Psychology and Graduate Program in Psychology, Universidade \\ Federal do Rio Grande do Norte, Natal, RN, Brazil
}

\begin{abstract}
The aim of this article is to analyze the changes in public policy against child labor introduced by the Brazilian government. The democratic processes of the 1980s in defense of social equity and justice, and the partnership with international organizations resulted in the ratification of international guidelines, the creation of specific legislation and the development of public policy against child labor in the 1990s. The result of this process was the Child Labor Eradication Program (PETI), which combined income transfer and education. Despite national and international criticism, its continuation was strongly supported for its contribution to the eradication of child labor. However, starting in 2005, the Brazilian government implemented a series of legislative changes in a supposed attempt to improve managerial effectiveness. The PETI was extinguished and replaced by an income transfer policy with a focus on poverty. Education and child labor, whose existence was mainly attributed to poverty, ceased to be the focus of public policy. Other policies followed a similar trajectory, emphasizing family rather than individual protection and assistance, through fragmented social services with a focus on extreme poverty, community surveillance, and universal access to education.
\end{abstract}

Keywords: Child labor, public policy, education.

\section{Quando a Educação Não é Solução: Política de Enfrentamento ao Trabalho Infantil}

\section{Resumo}

O objetivo deste artigo é analisar as mudanças empreendidas pelo governo brasileiro nas políticas públicas de enfrentamento ao trabalho infantil. O processo democrático do país na década de $1980 \mathrm{em}$ busca de equidade e justiça social, a parceria com organizações internacionais resultaram na ratificação das normas internacionais, criação de legislações específicas e constituição na década de 1990 de uma política pública: o Programa de Erradicação do Trabalho Infantil (PETI). O PETI aliava transferência de renda e educação. Apesar das críticas internas e internacionais recebeu recomendações de continuidade porque foi reconhecido como política de enfrentamento ao trabalho infantil. Mas a partir de 2005 o governo brasileiro empreendeu mudanças justificando a necessidade de aprimoramento da gestão. Extinguiu o PETI e instituiu outra política que focaliza transferência de renda e pobreza. Retirou o foco do trabalho infantil e da educação porque fez uma leitura de suas causas, essencialmente atreladas à po-

Mailing address: Rua Marieta Steimback Silva, 320, Edifício Maison Miramar, Apto 2802A, Bairro de Miramar, João Pessoa, PB, Brazil 58043-320. E-mail: jfalberto@uol.com.br 
breza. Deixou o foco da assistência e da proteção social no indivíduo e passou para proteção à família, através de serviços socioassistenciais fragmentados, focalizados na indigência e vigilância social em vez de investir em políticas educacionais e universais.

Palavras-chaves: Trabalho infantil, políticas públicas, educação.

\section{Cuando La Educación No es la Solución: Política de Enfrentamiento al Trabajo Infantil}

\section{Resumen}

El objetivo de este artículo es analizar los cambios realizados por el gobierno brasileño en las políticas públicas de enfrentamiento al trabajo infantil. El proceso democrático de la década de 1980 en busca de la equidad y la justicia social, la articulación con las organizaciones internacionales resultaron en la ratificación de las normas internacionales, la creación de una legislación específica y establecimiento, en la década de 1990, de políticas públicas: el Programa de Erradicación del Trabajo Infantil (PETI) aliándose la transferencia combinada de ingresos y la educación. A pesar de las críticas nacionales e internacionales, se recomendaba continuar el programa. Pero a partir de 2005, el gobierno brasileño llevó a cabo cambios en las políticas justificando la necesidad de mejorar la gestión. Se Extinguió el PETI y se instituyó como eje la transferencia de ingresos y la pobreza. Se retiró el foco del trabajo infantil, porque se hizo una lectura de sus causas, principalmente vinculada a la pobreza, el foco se convierte en la situación de riesgo y no en el proceso educativo. Se deja el enfoque de la asistencia y la protección social en el individuo y pasa a la protección de la familia, a través de servicios de asistencia social fragmentado, centrado en la indigencia y la vigilancia social en lugar de las políticas educativas y universales.

Palabras clave: Trabajo infantil, políticas públicas, educación.

The aim of this article is to analyze the changes in public policy against child labor introduced by the Brazilian government. Although the first policies concerning child labor involved both income transfer and education, they have since been modified to continue delivering social assistance and investing in the fight against poverty, without an accompanying educational policy.

According to Article 2 of Convention 138, in which the International Labor Organization (ILO) sets the norms for the minimum age for admission to employment, the specified minimum age should not be less than the age of completion of compulsory schooling. This conclusion has been supported by additional research (ILO, 1981) demonstrating the importance of education in preventing, suppressing and eradicating child labor. In a study of successful strategies for the prevention and eradication of child labor across 13 countries, the Organização Internacio- nal do Trabalho (OIT, 1999) found that full-time education was the main tool in this endeavor.

The analysis of child labor in Brazil must include the following questions: How has child labor been historically addressed in Brazil? What precipitated the partnership with the ILO partnership and the implementation of a public policy against child labor? What caused this policy to be changed starting in 2003 with the call of the World Bank for a fight against poverty? What caused the shift in focus of Brazilian public policy in 2005, from income transfer and education to poverty and the Community Participation and Strengthening Service (Serviço de Convivência e Fortalecimento de Vínculos [SCFV])? Why did Brazil change its policy on child labor? Why did Brazil select a social service policy over an educational policy? 


\section{Antecedents and Implementation}

The fight against child labor in Brazil began in 1891, with the promulgation of Decree 1313 , the first form of legal protection against child labor in the country, which prohibited children aged less than 12 years from obtaining employment or engaging in night-time activities (Rizzini, 2008). Although the 1824 Constitution does not address child labor, two decrees on the topic were issued in Rio de Janeiro between 1891 and 1924. In 1917, protection measures for the "work of minors" (in the terminology of the time) were determined in Decree 1801, while Decree 16300, issued in 1923, prevented those younger than 18 years from working for longer than 6 hours in a 24-hour period (Barros, 2010). The 1934, 1937 and 1946 Constitutions established a legal restriction on the age at which children and adolescents were allowed to enter the job market (Castro \& Castro, 2002). Working was prohibited until age 14 , night work until age 16, and hazardous work, until age 18 . The 1967 and 1969 Constitutions, on the other hand, forbade any work until age 12, and night and factory work until age 18 .

The legal prohibition of child labor in Brazil, which took place under immense social pressure, came about for two major reasons: (a) European labor laws passed in the Industrial Revolution, which influenced the Brazilian juridical doctrine and led to concerns being raised by both society and the judges themselves and society (Nascimento, Ferrari, \& Martins, 2002); (b) the ILO Conventions and Recommendations, most of which were signed by the Brazilian government (5, 6, 124, 138, 182 and 190).

Brazilian public policy on child labor was also preceded and followed by extensive data collection on this issue. The number of individuals aged 10 years or older who were currently employed had been investigated by the Brazilian Institute of Geography and Statistics (Instituto Brasileiro de Geografia e Estatística [IBGE]) as early as the 1970s. In 1985, the life situation of children and adolescents (referred to as "minors" after the Minor's Code of 1979) was also investigated by the National Household Survey
(Pesquisa Nacional de Amostragem Domiciliar [PNAD]) conducted by the same institution. In 1988, the employment rates of children and adolescents were $12.1 \%$ and $46.8 \%$, respectively (Fausto \& Cervini, 1991). The period between 1980 and 1991 saw a considerable increase in the urban population of children and adolescents whose families were headed by individuals who earned less than the minimum wage. In 1980, $4.6 \%$ of families with children aged between 0 and 17 years earned less than half the minimum wage. In the 1980s, Brazil had a population of 119 million, of whom 37.5 million or $18.8 \%$ were children and adolescents aged between 5 and 17 years. At the time, the richest $20 \%$ of the population accounted for $62 \%$ of the national income, while the poorest $40 \%$ accounted for only $8 \%$. In 1990, Brazil had a population of 147 million, of whom 44 million (29.9\%) were 5 to 17 years old. In 1991, the number of families with children aged 0 to 17 years who earned less than half the minimum wage increased to $12.8 \%$. The number of working children aged 5 to 17 was 9.6 million in 1992, and 9.5 million in 1995 (Schwartzman, 2004).

By the end of the 1980s, Brazil had become known for its social inequality, income concentration, misery, underdevelopment, corruption and neglect, all of which had dire consequences for children (ILO, 2003). The failure of closed institutions, together with "the . . ethical and political rejection of certain sectors of society" (Costa, 1990, p. 32), and the increasing sensitivity to human rights issues brought about by the protest movements organized by civil society at the end of the military rule, created a novel sense of awareness, in the form of a new attitude toward children and adolescents. At the same time, an economic crisis led to a sharp decrease in federal funding and the competitiveness of Brazilian industry, whose technology became increasingly outdated as a result of several factors, including a closed economy policy. The recession which characterized the 1980s reflects the deterioration of peripheral Fordism and the resulting rise in unemployment, precariousness and informality. On the other hand, this scenario also gave rise to an 
intense social movement, which led to the creation of several organizations (Borges \& Druck, 1993) including those which fought for the recognition of children and adolescents as subjects of rights, and elaborated the Statute on Children and Adolescents (Estatuto da Criança e do Adolescente [ECA]).

These data demonstrate the alarming situation of children and adolescents in the late 1980s, especially with regards to child labor, the institutionalizing practices of the Foundation for the Well-being of Minors (Fundação de BemEstar do Menor [FUNABEM]) - an organization with an assistentialist and repressive philosophy which removed children from their homes and placed them in institutions for "recovery" - and the violence and murder of children living on the streets. Brazilian society was deeply touched by these issues, and after organizing civil movements such as the "Diretas jă" ("Direct [elections] now") and "Constituinte" ("Constituent"), which fought for direct presidential elections and a new constitution, respectively, began to vindicate the rights of children and adolescents. Over 200,000 signatures were gathered in support of popular issues, and a letter of demands was drafted and signed by 1.4 million children. The two amendments known as "Child and Constituent" and "Children: a National Priority" gave rise to articles 227 and 228 of the Federal Constitution of 1988, and later, the ECA (Movimento Nacional de Meninos e Meninas de Rua [MNMMR], 1994).

It was in this historical moment, riddled with conflict and political struggles, that the concepts of a "subject of rights" and "full protection" began to take shape. This marked a significant departure, at least in the legal sense, from the perception of children and adolescents as 'irregular.' These changes were described by Costa, Kayayan and Fausto (1991) in terms of their impact in the content, methods and management of public policy: (a) contents were changed when public policies were grouped and classified as either "basic" or "special," and redesigned to address the right to a legal defense, as well as medical and psychosocial care; (b) methods changed with the introduction of so- cioeducational interventions in place of repression, and guaranteeism in place of irregularity; (c) management changed with the introduction of popular participation in policy-making and control through representative entities (municipal, state and federal councils for children and adolescents).

In 1990, in the wake of the democratic transition and the defense of constitutional rights, the Brazilian government ratified the United Nations (UN) Convention on the Rights of the Child. One of the pillars of the Convention is the right of children and adolescents to be protected from economic exploitation and from performing any work that is likely to be hazardous, interfere with their education, or represent harm to their health and/or physical, mental, spiritual, moral or social development (Article 32; Fundo das Nações Unidas para a Infância [UNICEF], 1989). After these legal milestones, child and adolescent labor became a priority for governments and society as a whole.

In addition to these historical landmarks in Brazil's democratic trajectory and quest for equity and social justice, there is the country's participation in the International Program on the Elimination of Child Labor (IPEC), and articulation with the UNICEF. These initiatives resulted in the ratification of international guidelines, the implementation of specific legislation, as well as partnerships which led to the adoption and development of public policies, and the creation of opportunities for discussion and articulation with government and non-government agencies, such as the National Forum for the Prevention and Eradication of Child Labor (Fórum Nacional de Prevenção e Erradicação do Trabalho Infantil [FNPETI]). The latter is "an opportunity for dialogue, consensus-building, advocacy and public policy to protect the fundamental rights of children and adolescents" (FNPETI, 2013, p. 2).

The Brazilian government then developed and implemented a public policy against the early employment of children and adolescents. The initiative consisted of an ILO pilot project, implemented in the Fields of Goitacazes, Rio de Janeiro, in 1992. Children were removed from sugarcane fields and domestic work, and pro- 
vided with scholarships and after-school activities in partnership with FUNABEM, who was responsible for school provision.

In 1995, this protocol was replicated in an experimental initiative known as the Integrated Action Program (Programa de Ações Integradas [PAI]). The aim of the PAI was to provide a working methodology for all participating organizations. The concept was developed in the FNPETI as a result of discussions involving several government and non-government institutions. The state of Mato Grosso do Sul was given priority in the implementation of the program, due to the high number of children and adolescents reported to be working in hazardous conditions in yerba mate harvesting and coal plants in 14 different cities. The work at coal plants is hazardous and exposes children and adolescents to physical conditions such as excessive heat from the ovens and the sun, that are far too extreme for their level of development (Carvalho, 2004).

In 1996, with the support of the IPEC, the PAI was transformed into the Program for the Eradication of Child Labor (Programa de Erradicação do Trabalho Infantil [PETI]). The PETI was implemented as an experimental program, assisting 893 children and adolescents. By December of the following year, 1985 children and adolescents from $43 \%$ of the cities in the state of Mato Grosso had enrolled in the program, demonstrating its tendency to expansion. According to the ILO (2003), until the program was implemented, children and adolescents who worked at coal plants or yerba mate plantations had never had access to school.

In 1996, the PETI was extended to the sugarcane-growing region of Pernambuco, and the sisal-producing region of Bahia. In 1998, it grew to include the citrus-growing region of Sergipe, the gold mining region of Rondônia, and the sugarcane plantations of Rio de Janeiro. In 1999, the PETI extended to other states, including Alagoas, Paraiba, Rio Grande do Norte, Espírito Santo, Santa Catarina and Pará, and began to enroll children and adolescents who lived in urban regions and worked at landfill sites (OIT, 2001).

The first policy specifically directed at child labor in Brazil involved several institutions ar- ticulated into a network, with each playing a different role in the project outcome. The Ministry of Work and Employment would screen and identify working children and adolescents through Regional Work Units, and send the list of names for enrollment in the PETI. Participants would be signed up to the program by the Social Action Department of each city, while civil society was responsible for social control in all cities and states through the Commissions for the Prevention and Eradication of Child Labor. The commissions had a propositional and consultative role, and sought to assist the implantation, implementation and management of the PETI.

The PETI was developed by the Federal Government in association with participating cities to remove children and adolescents aged 7 to 15 years from dangerous, difficult, hazardous or degrading work, which posed risks to their health and development, while providing them with access to formal education, tutoring, and access to artistic, cultural, sport and leisure activities after school. The program consisted of articulated initiatives which conditioned financial support (Child Citizen Allowance) on school enrollment and attendance. Parents were also required to receive professional training. Families in the PETI who lived in rural areas or cities with less than 250,000 inhabitants received $\mathrm{R} \$ 25.00$ per child or adolescent, while those who lived in urban regions with more than 250,000 inhabitants received $\mathrm{R} \$ 40.00$ per child. These values were conditional upon a minimum attendance of $75 \%$ to both school and after-school activities (Ministério do Desenvolvimento Social e Combate à Fome [MDS], 2004). Interestingly, the latter received many different names over the course of time. These were first introduced as an "extended period" in MDS Ordinance 428, issued in 2001; in MDS Ordinance 466, issued in 2005, they were "Socioeducational Activities"; in 2007, they were described as "Socioeducational Services" by the National Department of Social Work, in MDS 01 (MDS, 2010a).

Despite the implementation of the PETI, according to the IBGE, 7.7 million children between 5 and 17 years were still working as 
of 1998. These data suggested that, although child labor decreased, there was a need for other interventions in addition to the PETI, which led to increasing levels of national and international pressure. This pressure was exerted in the form of an international social movement: the Global March Against Child Labor, which was created in a meeting of 27 organizations from the Americas, Europe, Asia and Africa, in The Hague, Netherlands, and eventually spread to 85 countries. The aim of the march was to raise worldwide awareness of the need to protect and promote children's rights, especially the right to free quality education, protecting them against economic exploitation and any form of work.

On an internal level, the demand for further action was met with the approval of amendment 20. However, this was also an attempt to align national laws with the international standards the country was pressured to adopt, such as ILO Conventions 138 and 182. Convention 182, which addresses the worst forms of child labor, was ratified by Brazil in the year 2000. Yet despite the ratification of Convention 182, which was established by the ILO in 1999, Brazil was not yet a signatory of Convention 138, the minimum age convention, established in 1973.

Although the contents of the latter had been sent to the Brazilian National Congress in 1974, the convention was only ratified in 2002 , after being rejected by the Senate Committee on Constitution, Justice and Citizenship in 1991 on the grounds of incompatibility with constitutional guidelines on the minimum age for employment. The legal minimum age for employment was only modified in constitutional amendment 20, issued on December 15th 1998, which altered item XXXIII in article 7 of the Federal Constitution, increasing the minimum age for employment in Brazil from 14 to 16 years, and the minimum age for apprentice employment from 12 to 14 (Decreto Legislativo $N^{\circ} 179,1999$ ).

Even after ratifying Convention 182, it took eight years for Brazil to issue a list of the worst forms of child labor, which was released on June 12th 2008, in the form of Decree no. 6481. In addition to defining the concept of "worst forms of child labor," which includes activities that are harmful to children's health, safety or morals, the document lists 93 activities and their potential risks to working children. Although nearly a decade elapsed between the ratification of the Convention and the signing of the Decree, the list only began to be enforced after significant pressure from civil movements encouraged by the FNPETI and the National Council for the Rights of the Child and the Adolescent (Conselho $\mathrm{Na}$ cional dos Direitos da Criança e do Adolescente [CONANDA]) with the support of the ILO.

Through the IPEC, the ILO implemented over 100 programs against child labor (OIT, 2010). The international visibility of child labor in Brazil once again prompted the cooperation of the ILO, which funded a supplement to the PNAD. The survey was financed by the Statistical Information and Monitoring Program on Child Labor (SIMPOC) and conducted by the IPEC (Schwartzman, 2004). The aim of this supplemental survey was to investigate child labor between the ages of 5 and 17, whose prevalence in 2001 was estimated at 5.4 million (Kassouf, 2004). According to the survey, $86 \%$ of children aged 5 to 17 were currently in school, while $12.7 \%$ were employed, and $12.1 \%$ were not in school. In $14.7 \%$ of cases, the reason for non-attendance was the absence of schools near the child's home. Lastly, $15.5 \%$ of the children surveyed were enrolled in government programs targeting education. The 2001 PNAD survey also revealed that school enrollment rates were lower among working children, at $80.3 \%$, than the remaining children and adolescents, of whom 91.1\% were currently in school (Kassouf, 2004).

As part of the international social movement to protect the rights of children and adolescents, the 2002 UN Millennium Summit established a list of development goals, which focused on peace, safety, the eradication of poverty, the environment and human rights. As a consequence of the Summit, social movements articulated with the government in order to develop a series of nationwide plans such as the II National Human Rights Program (Plano Nacional de Di- 
reitos Humanos [PNDH II]) in 2002, and the I National Program for the Prevention and Eradication of Child Labor and Protection of the Adolescent Worker (Plano Nacional de Prevenção e Erradicação do Trabalho Infantil e Proteção ao Trabalhador Adolescente), in 2004. The National Human Rights Program included a proposal for the extension of the PETI to children and adolescents in urban regions who are exposed to risk, commercial sexual exploitation, illegal activities and drug trafficking, as well as greater support for income generation by participating families, and the promotion and dissemination of socioeducational activities for the families of participating children. The I National Program for the Prevention and Eradication of Child Labor and Protection of the Adolescent Worker, on the other hand, became the legal reference for the eradication of child labor and the implementation of the PETI, proposing the extension of the program to all forms of child labor and all Brazilian cities (MDS, 2004), since, as of 2002, only 2601 cities took part in the program (MDS, 2004).

In addition to giving rise to the two national programs which clearly acknowledged the importance of the PETI, an assessment of its outcomes between 2000 and 2003 in $98 \%$ of participating cities demonstrated an association between PETI initiatives and reductions in child labor (MDS, 2004). Nevertheless, the program was also criticized for its management, insufficient infrastructure for socioeducational activities, and inability to improve the living conditions and perspectives of participating families (Carvalho, 2004).

Assessments of the PETI by authors and institutions (Cacciamali, Tatei, \& Batista, 2010; Carvalho, 2004; Instituto de Pesquisa Econômica Aplicada [IPEA], 2008; Rua, 2007) discussed its low efficacy relative to its cost, the flaws in its implementation (e.g. insufficient coverage of working children), delays in the provision of financial benefits, the lack of support by municipal authorities, as well as the lack of supervision of program activities. In spite of the criticism, authors (Cacciamali et al., 2010; Carvalho,
2004; IPEA, 2008; Rua, 2007) supported the continuation of the Program, recommending its separation from other income transfer initiatives due to its unique characteristics, such as its focus on working children and required attendance to school (Alberto, Costa, Belém, Sousa, \& França, 2015) and educational after-school activities (Ferreira, 2002).

The support for the continuation of the PETI went as far as the IPEC/ILO, who claimed that "Brazil created the greatest program against child labor in the world" (Oliveira, 2006, p.92). Despite the establishment of legal guidelines, the attempts of the FNPETI and the CONANDA to organize civil society, the creation of a National Committee for the Eradication of Child Labor (CONAETI) based on a four-fold participation model, and the continued presence of the ILO in Brazil since 1992, the federal government went on to dismantle the PETI, at least as a specific public policy instrument against child labor, starting in 2005 and culminating in 2013.

Civil movements, including the creation of a protectionist legislation in the 1990s, resulted in the implementation of a public policy against child labor which arose from the articulation of civil society and the government. This often took the form of the four-fold structure fostered by participative democracy, which allows civil society to secure greater control over public administration. Though the participative model prevails in the political system, the year 2005 saw the implementation of several measures by the Brazilian government with the aim of improving management structures and instituting a new model of public policy against child labor. Contrary to the participative model, this was done with no external consultation. The PETI was extinguished and replaced by a new type of policy with a focus on income and poverty. Although the legal positivization of rights for children and adolescents was an important achievement, Brazil was unable to effectively protect this population, since the changes implemented were insufficient to transform the social context which continues to cause injustice, inequality and child labor. 


\section{Changes in Public Policy against Child Labor}

In 2003, the World Bank invited all countries with a high prevalence of child labor to discuss the situation and the need to act against poverty, which was considered the cause and consequence of child labor, based on "the specialized international literature in which poverty is often cited as the main reason for the persistence" (Cacciamali et al., 2010, p. 276) of child labor. What made PETI unique was the combination of income transfer and educational initiatives. Yet in 2005, in a supposed attempt to increase program coverage, rationalize and improve its management, and provide assistance and protection to at-risk families and adolescents, the federal government integrated the PETI into the Family Grant Program (Programa Bolsa-Família [PBF]; Rua, 2007). The original PETI model, in which families were provided with financial aid in the form of grants, while children participated in educational activities in an extended school period, was thus modified. In other words, the Brazilian government gave up on the original PETI model, which arose from the social policies of the 1990s and the need for a minimum income program which addressed both hunger and poverty through a combination of education and income transfer (Silva, Yaszbek, \& Di Giovanni, 2007), in favor of "programs focused on poverty and increased purchasing power" (Behring \& Boschetti, 2011, p. 185), much like the combination of the PETI and PBF.

The focus was no longer child labor, which was assumed to be caused by poverty, and Brazil followed the global trend in social policy on poverty in the 21 st century, with the return of a police state (Wacquant, 2001) and increased investment in income assurance programs to provide indirect, state-funded salaries (Behring $\&$ Boschetti, 2011). The result was a compensatory and repressive social protection policy. The changes implemented from 2005 onwards shifted the focus of public policy to the situation of risk rather than the educational process, unlike the original version of the PETI manual (OIT, 2003), which described the extended school pe- riod as a time and place for "learning, educational support as well as sport, cultural, artistic and leisure activities" (p. 7).

As can be seen in subsequent documents issued by the MDS, especially the National List of Socio-assistential Services published in 2009, the focus continues to be on the family, but is addressed through social and assistential services based on protective measures which encourage peaceful coexistence, such as social work and observation, performed by the Social Assistance Reference Centers (Centro de Referência da Assistência Social [CRAS]).

Brazil currently faces an apparent stagnation, although official figures reveal a significant decrease in child labor between 1992 and 2012. However, the official data also reveals a number of oscillations. In 1992, the number of working children aged 5 to 17 was 9.6 million. This figure decreased by $56 \%$ to 5.4 million in 2002 . It fell to 5.1 million in 2003, before increasing to 5.3 million in 2004. Numbers continued to rise in 2005 to 5.9 million, but decreased to 5.3 million in 2006. Estimates decrease further to 4.8 in 2007, and again to 4.4 in 2009. The data continuously fluctuate. According to the 2010 Census, 3.4 million children aged between 10 and 17 years were currently employed, while the 2011 PNAD survey, using a different methodology, put the number of working children between the ages of 5 and 17 years at 8.6 million (Ministério Público do Trabalho [MPT], 2012).

An assessment of the I National Program for the Prevention and Eradication of Child Labor and Protection of the Adolescent Worker also revealed that less than a third of the 133 initiatives planned were implemented as expected (Ministério do Trabalho e Emprego [MTE], 2011). As a result, the Brazilian government implemented the II National Program for the Prevention and Eradication of Child Labor and Protection of the Adolescent Worker, with the aim of eradicating the worst forms of child labor by 2016, increase the number of adolescents in apprenticeships and eradicate all forms of child labor by 2020 ; Their commitment to this goal was demonstrated by their offer to host the III Global Conference on Child Labor in 2013, as a country 
with an international reputation for their fight against child labor, which decreased nationally by $67 \%$ from 2000 to 2012, while global child labor rates decreased by only $36 \%$ in the same period. Brazil reiterated its commitment on an international level by signing the Brasilia Declaration along with the 154 countries present in the conference, pledging to free 168 million children, 85 million of whom engaged in the worst forms of child labor, from illegal employment (ILO, 2013).

The PETI is internationally recognized as a model intervention against child labor (ILO, 2013). Its reputation is supported by the national literature, which has evaluated the program in its attempt to combine income transfer with educational activities, with an emphasis on learning support. Improvements in the academic performance of children enrolled in the program were described by Carvalho (2004), while Ferreira (2002) evaluated the association between the PETI and public education in the state of Pernambuco by interviewing teachers working in extended day schools. The author found the program to have an immediate and significant impact on education in the cities studied, especially due to the school attendance requirements for financial aid.

On a similar note, Alberto et al. (2015), analyzed the contribution of the PETI to the schooling of children and adolescents removed from illegal employment from the perspective of educators, teachers, administrators and staff. The authors found that all those involved at different levels of the program believed it made a significant contribution to the education of participating children and adolescents, and acknowledged that participants preferred the PETI to working precisely because it allowed them to continue studying.

The socioeducational activities involved in the program are also believed to have a positive impact on language development, and help children become less inhibited (Duryea \& Morrison, 2004; Ferreira, 2002). According to the authors, cash transfer programs with an educational component have a positive and effective impact on participants. This effect is attributed to the reduction in the time children dedicate to work, and also to improvements in children's educational attainment (Duryea \& Morrison, 2004).

To ensure a data-driven approach to the inclusion of the PETI in the Unified Social Assistance System (Sistema Único de Assistência Social [SUAS]), the Department of Assessment and Information Management (Secretaria de Avaliação e Gestão da Informação [SAGI]) of the MDS conducted a quantitative survey in 120 cities and a qualitative study in 40 cities in 2008, to demonstrate the contribution of the PETI to the eradication of child labor. The data confirmed the effectiveness of the program and its value as a model of learning support, demonstrating the impact of the PETI on child labor rates through its educational program. However, in 2009, the Department of Special Protection (Departamento de Proteção Especial [DPSE]) of the MDS was tasked with the responsibility of elaborating the documentation for the management and operationalization of the PETI and the methodology of the SCFV.

Despite the positive internal assessment of the PETI, as well as its international recognition and replication, its integration with the Family Grant Program beginning in 2005 continued to undermine it as a public policy against child labor:

... Brazil has in recent years turned from solely a beneficiary of technical support through IPEC, to becoming a provider of assistance to others . . . Brazil and the ILO launched an initiative to promote specific South-South technical cooperation projects and activities that contribute to eliminating child labor, which also embraces South Africa and India (OIT, 2010, p. 22).

The focus shifts from child labor and education with the PETI to poverty and social assistance with the SCFV, in a supposed attempt to address the aims of the National Social Assistance Policy (Política Nacional de Assistência Social; PNAS), which include the protection and security of families and the community. According to the documents elaborated by the MDS (2010a), 
It is important for the service to invest in different forms of expression and the creation of a participative space which leads to achievements compatible with social assistance policy, while gradually distancing itself from its role as a source of learning support (p. 13).

The text goes on to say that those who attend extended-day schools must take part in the activities organized by Social Assistance Reference Centers (CRAS) in the local service network. The aim of the document is to guide the implementation and improvement of SCFV services for children aged 6 to 15 years. According to the MDS, one important reason for this change was the implementation of a policy specific to children and adolescents aged between 6 and 15 years within the SUAS (MDS, 2010a).

Why was the PETI included in the SUAS? According to the MDS, after the approval of the National Social Assistance Policy in 2004, it was "imperative that the SUAS be implemented in a way that facilitated the regulation and organization of a decentralized and participative management model" throughout the country (MDS, 2010b, p. 51). As mentioned by the Ministry itself, the integralization was perceived as an "assurance of management rationalization and improvement, and of increased coverage of illegally employed children and adolescents, as well as the extension of SCFV initiatives to working children and adolescents in the Family Grant Program" (MDS, 2010b, p. 44). In other words, the policy against child labor was defined a policy to eradicate poverty. Concerns regarding the operationalization of the management system and increased coverage appear secondary to the need to target particular age groups. This would be a valid line of reasoning if attempts to eradicate poverty did indeed result in decreased social inequality through the equal division of wealth. However, this is not the aim of the income transfer program.

Further changes continued through to 2013, when Resolution 008, issued in April of that year by the National Council of Social Assistance (Conselho Nacional de Assistência Social
[CNAS]) of the MDS, eliminated the PETI by excluding it from the list of activities performed by the SUAS. The modifications made since the beginning of its amalgamation with the Family Grant Program in 2005 ended in the restriction of the PETI to only 1031 cities. As of 2005, when the changes began to be implemented, the PETI was active in 2788 cities (MDS, 2005) under the direct management of municipal authorities (in some cities, the program was managed by the state). Resolution 008 restricted eligibility criteria for the program. The PETI continued to be active in cities with over 400 cases of child labor reported in the 2010 Census, or an increase of over 200 cases between census surveys conducted in 2000 and 2010. As a result of these changes, although several educational initiatives were implemented by federal and state governments, these were no longer the focus of public policy on child labor.

\section{When Education is Not the Solution}

Although Brazil invested heavily in social assistance policies in the fight against child labor, combining income transfer and education through the conditionality of transfers on school attendance, public policies on social assistance and education were never fully articulated, neither in theory nor in practice. Instead, both were developed in parallel.

Brazil invested in several initiatives to improve educational attainment, starting with Law no. 9.394, issued in 1996, and known as the National Educational Guidelines and Framework Law (Lei de Diretrizes e Bases da Educação Nacional), which officially defined and categorized educational attainment into two levels. The first, known as Basic Education, was further divided into Child Education, Primary Education and Secondary Education. Primary Education became mandatory and a responsibility of the state. Its provision became a priority, and was guided by the following objectives: (a) universal access to public education; (b) keeping children and adolescents in school, and (c) promoting a gradual reduction in child labor rates. 
The following programs were then implemented to achieve the aforementioned goals: The Education Salary, and the Primary Education Maintenance and Development and Teacher Appreciation Fund (Salário Educação e o Fundo de Manutenção e Desenvolvimento do Ensino Fundamental e de Valorização do Magistério [FUNDEF]), in 1996; the National School Nutrition Program (Programa Nacional de Alimentação Escolar [PNAE]), which had existed since 1955 but was decentralized in 1994; National Textbook Program (Programa Nacional do Livro Didático [PNLD]), which had existed since 1929 but suffered the consequences of budget cuts and alterations in 1993, at which point changes were made to ensure the program received reliable financial support; Money Straight to School Program (Dinheiro Direto na Escola [PDDE]), created in 1995; the National School Transportation Program (Programa Nacional de Transporte Escolar [PNTE]) created in 2004; the National School Library Program (Programa Nacional Biblioteca da Escola [PNBE]) created in 1997; the Fundescola National Program for Information Technology in Education (Fundescola, Programa Nacional de Informática na Educação [PROINFO]), created in 1997 (Kassouf, 2004) and restructured in 2007; Youth and Adult Education (Educação de Jovens e Adultos [EJA]) and the National Program for the Integration of Technical and Basic Education in Youth and Adult Education (Programa Nacional de Integração da Educação Profissional com a Educação Básica na Modalidade de Educação de Jovens e Adultos [PROEJA]), created in 2006; the National School Health Program (Programa Nacional de Saúde Escolar [PNSE]), created in 2006; and the National Fund for Basic Education (FUNDEB), which replaced the FUNDEF starting in 2006.

These educational programs did not specifically focus on child labor, and as such, the Brazilian government created income transfer programs such as the School Grant, the PETI and the Family Grant programs, which, at least in their initial stages, addressed both educational and social service needs. As time went on, the
Family Grant program absorbed several income transfer initiatives (school grants, food vouchers, gas vouchers and the PETI), so that its focus shifted from individual assistance and protection to the protection of families (Kassouf, 2004).

These educational policies do have an impact on child labor rates (Di Giovanni, 2004), but are not specifically designed to tackle this issue. Cacciamali et al. (2010) as well Kassouf, Nunes, Pontili and Rodrigues (2004) as support its claim in their analysis of the Family Grant Program, which lists the reduction of child labor rates as one of its objectives. However, the authors conclude that this goal is not clearly addressed by program rules, which do not require parents and guardians to remove their children from work. Furthermore, the efficacy of the program in achieving this particular objective has not been proved. Cacciamali et al. (2010) find that the Family Grant Program does improve school attendance, but also contributes to increasing child labor rates. On a similar note, the literature on the impact of income transfer programs on the education of working children and adolescents has also found that, while these initiatives have a positive effect schooling, they have no impact on child labor rates (Cacciamali et al., 2010; Cardoso \& Souza, 2004). However, studies performed in Latin America and the Caribbean demonstrate that income transfer programs conditional on participation in extracurricular or after-school activities lead to higher school attendance rates and fewer hours of work (Bouillon \& Tejerina, 2006; Handa \& Davis, 2006). This is the case of the PETI, which involved both income transfer and an educational component.

\section{By Way of Conclusion}

To suggest that poverty is a cause and consequence of child labor is to ignore the associations of the latter with capitalism and social inequality. The assumption that a sectorial and fragmented policy would be able to address a structural problem is equally inaccurate. Child labor is part of the exploitation of man by man (Marx \& Engels, 2007). In this particular case, it is children and adolescents who are exploited 
by capitalism. In capitalist systems, rights take on a paradoxical character in that they are both a means of regulating conflicts between classes (Lukács, 1978) but also a tool wielded by workers in the social struggle (Singer, 2010). The creation of social rights is the result of the fight for workers' rights. "Only the working class is subject to social rights, as these only apply to people whose situation warrants their use" (Singer, 2010, p.191). However, as demonstrated by a historical analysis of working class struggles for labor rights and standards, worker rights are at least procedurally assured by current legislation on human rights and social policy.

As a result, child labor can be understood as a consequence of capitalism and social issues. These social issues consist of the set of political, social and economic problems, which arise from the contradiction between capital and labor created in the formation of a capitalist society (Yamamoto \& Oliveira, 2010) as a result of social inequality. The latter, in turn, can only be ended through the social transformation achieved by class struggles. Social struggles have eliminated the private ownership of capital and labor, and put the State in a position to advance human rights and social policy "In capitalist society, legal relationships are only justified by the inherently unequal nature of class society" (Iamamoto, 2009, p. 280), since Laws are a tool of the bourgeoisie. However, they can also be used as a tool by the working class in their struggle for rights against the Capital.

Social policy can serve a similar purpose, as it also contributes to social protection and addresses the social issues which arise as a result of the capitalist production process (Behring \& Boschetti, 2011). Educational policies, for instance, are universal, essential, and all-inclusive. Social service policies, on the other hand, distance themselves from this model, as they are conditional, segmented and no longer universal, as their focus on poverty restricts their applicability to specific sectors of the population. As a result, social service policies in Brazil and Latin America are powerless in offering universal access to goods and services (Iamamoto, 2009).
The Brazilian government chose to fight child labor by adopting social service but not educational policies, for an approach that is inherently inadequate precisely for its lack of universality. Social service policies are less costly due to their selective and conditional nature, and though they may reach certain sectors of the population, they are certainly not universal (Behring \& Boschetti, 2011). In its quest to enact political change based on budgetary concerns, the State eventually reaches social security, the core of social policy, and places restrictions on citizen rights.

Like many similar initiatives, social movements in defense of child and adolescent rights were valuable political tools in the confrontation of the authoritarian state, but unfortunately, restricted themselves to the defense of citizen rights rather than seeking a radical change in the capitalist system. As such, "their political dimension was confined to their immediate horizons, restricting their ability to situate themselves in the larger economic, social and political landscape of the class struggles" (Montaño \& Duriguetto, 2011, p.266). This particular feature of the class struggle may explain the fragility of partnerships between the State and social movements, whose struggles paved the way for the creation of several laws, but failed to prevent the stripping of protective social policies following international requests for political adjustments to budget allocation and spending, leading to radical changes in the relationship between the state and social movements (Iamamoto, 2009) after the modification of government policy against child labor.

That is not to say the PETI alone could ever guarantee the emancipation of children and adolescents (Tonet, 2005). Schools still fail to promote emancipatory activities for working class children, which comes as no surprise, since emancipation is impossible in capitalist society (Tonet, 2005). Although the aim of educational policies is not to eradicate child labor or eliminate hunger and poverty, they are important tools for social transformation, as they contribute to the construction and reproduction of the social beings who are capable of producing change. 


\section{References}

Alberto, M. F. P., Costa, R. R., Belém, K. K. G., Sousa, S. P., \& França, J. M. (2015). Programa de Erradicação do Trabalho Infantil e Escola. Ciência e Profissão, 28(1), 558-573.

Barros, A. M. (2010). Contratos e regulamentações especiais de trabalho ( $4^{\text {rd }}$ ed.). São Paulo, SP: LTr.

Behring, E. R., \& Boschetti, I. (2011). Política social: Fundamentos e história ( $9^{\text {rd }}$ ed.). São Paulo, SP: Cortez.

Borges, A., \& Druck, M. G. (1993). Crise global, terceirização e a exclusão no mundo do trabalho. Caderno CRH, 19, 22-45.

Bouillon, C. P., \& Tejerina, L. (2006). Do we know what works? A systematic review of impact evaluations of social programs in Latin America and the Caribbean [Working Paper]. Inter-American Development Bank, Sustainable Development Department.

Cacciamali, M. C., Tatei, F., \& Batista, N. F. (2010). Impactos do Programa Bolsa Família federal sobre o trabalho infantil e a frequência escolar. Revista de Economia Contemporânea, 14(2), 269-301.

Cardoso, E., \& Souza, A. P. (2004). The impact of cash transfers on child labor and school attendance in Brazil [Working Paper]. Department of Economics, Vanderbilt University. Retrieved from http://discoverarchive.vanderbilt.edu/bitstream/handle/1803/20/vu04-w07. pdf? sequence $=1 \&$ isAllowed $=\mathrm{y}$

Carvalho, I. M. M. (2004). Algumas lições do Programa de Erradicação do Trabalho Infantil. São Paulo em Perspectiva, 18(4), 50-61.

Castro, J. A. L., \& Castro, D. S. L. (2002). Aspectos jurídicos da proibição do trabalho infantil e da proteção ao trabalho adolescente. In M. E. Marques, M. A. Neves, \& A. Carvalho Neto (Eds.), Trabalho infantil: A infância roubada (pp.61-78). Belo Horizonte, MG: Ministério do Trabalho e Emprego.

Costa, A. C. G. (1990). Participar é preciso. Rio de Janeiro, RJ: Bloch.

Costa, A. C. G., Kayayan, A., \& Fausto, A. (1991). Do avesso ao direito de menor a cidadão. In A. Fausto \& R. Cervini (Eds.), O trabalho e a rua: Crianças e adolescentes no Brasil urbano dos anos 80 (pp. 9-14). São Paulo, SP: Flacso.
Decreto Legislativo $N^{\circ} 179$, de 1999. (1999). Aprova os textos da Convenção n. 138 e da Recomendação n. 146 da Organização Internacional do Trabalho (OIT), sobre a Idade Mínima de Admissão ao Emprego. Retrieved from http://www2.camara.leg.br/legin/fed/decleg/1999/decretolegislativo-179-14-dezembro-1999-370761-exposicaodemotivos-143183-pl.html

Di Giovanni, G. (2004). Aspectos qualitativos do trabalho infantil no Brasil. Brasília, DF: Organização Internacional do Trabalho.

Duryea, S., \& Morrison, A. (2004). The effect of conditional transfers on school performance and child labor: Evidence from an ex-post impact evaluation in Costa Rica [Working Paper]. Washington, DC: Inter-American Development Bank. Retrieved from http://www.iadb.org/res/ publications/pubfiles/pubWP-505.pdf

Fausto, A., \& Cervini, R. (Eds.). (1991). O trabalho e a rua: Crianças e adolescentes no Brasil urbano dos anos 80. São Paulo, SP: Flacso.

Ferreira, R. A. (2002). Política educacional e poder local: Análise das repercussões do Programa de Erradicação do Trabalho Infantil na educação de municípios pernambucanos. Revista Brasileira de Educação, (19), 99-119. doi:http://dx.doi. org/10.1590/S1413-24782002000100009

Fórum Nacional de Prevenção e Erradicação do Trabalho Infantil. (2013). Prevenção e Erradicação do trabalho Infantil: Compromissos que unem os integrantes do Fórum Nacional de Prevenção e Erradicação do Trabalho Infantil. Brasília, DF: Author.

Fundo das Nações Unidas para a Infância. (1989). Convenção Internacional dos Direitos da Criança. Retrieved from http://www.unicef.org/ brazil/pt/resources_10120.htm.

Handa, S. \& Davis, B. (2006). The experience of conditional cash transfers in Latin America and the Caribbean. Development Policy Review, 24(5), 513-536. doi:10.1111/j.14677679.2006.00345.x

Iamamoto, M. V. (2009). Questão social, família e juventude: Desafios do trabalho do assistente social na área sociojurídica. In M. A. Sales, M. Matos, \& M. C. Leal (Eds.), Politica social, família e juventude (pp. 261-298). São Paulo, SP: Cortez.

International Labour Organization. (1981). Minimum age - General Survey of the reports relating to 
Convention $n^{\circ} 138$ and Recomendation $n^{\circ} 146$ concerning minimum age. Retrieved from http:// blue.lim.ilo.org/cariblex/pdfs/ILO_Convention_138.pdf

International Labour Organization. (2013). III Conferência Global sobre Trabalho Infantil. Declaração de Brasília sobre trabalho infantil. 8 a 10 de outubro de 2013. Retrieved from http://www.ilo.org/ipecinfo/product/download. do? type $=$ document\&id $=23483$

Instituto de Pesquisa Econômica Aplicada. (2008). Boletim de Políticas Sociais: Acompanhamento $e$ análise $\left(15^{\text {rd }}\right.$ ed.). Brasília, DF: Ministério de Estado Extraordinário de Assuntos Estratégicos.

Kassouf, A. L. (2004). O Brasil e o trabalho infantil no início do século 21. Brasília, DF: Organização Internacional do Trabalho.

Kassouf, A. L., Nunes A. A., Pontili, R. M., \& Rodrigues, F. A. (2004). Análise das políticas $e$ programas sociais no Brasil. Brasília, DF: Organização Internacional do Trabalho.

Lukács, G. (1978). As bases ontológicas do pensamento e da atividade do homem. Temas de Ciências Humanas, 4, 1-11.

Marx, K., \& Engels, F. (2007). O manifesto do partido comunista. São Paulo, SP: Cortez.

Ministério do Desenvolvimento Social e Combate à Fome. (2004). Análise situacional do Programa de Erradicação do Trabalho Infantil - PETI. Brasília, DF: Fundo das Nações Unidas para a Infância.

Ministério do Desenvolvimento Social e Combate à Fome. (2005). Levantamento de beneficiários do Programa de erradicação do trabalho infantil. Retrieved from http://www.mds.gov.br/sagi

Ministério do Desenvolvimento Social e Combate à Fome. (2010a). Orientações técnicas sobre o serviço de convivência e fortalecimento de vínculos para crianças e adolescentes de 6 a 15 anos: Prioridade para crianças e adolescentes integrantes do Programa de Erradicação do Trabalho Infantil. Brasília, DF: Author.

Ministério do Desenvolvimento Social e Combate à Fome. (2010b). Gestão do Programa de Erradicação do Trabalho Infantil no SUAS: Orientações técnicas. Brasília, DF: Author.

Ministério Público do Trabalho. (2012). Ranking do trabalho infantil nos estados brasileiros - 5 a 17 anos - PNAD 2011. Retrieved from http:// peteca2008.blogspot.com.br/2012/09/rankingdo-trabalho-infantil-no-brasil_23.html?spref=bl

Ministério do Trabalho e Emprego. (2011). Plano Nacional de Prevenção e Erradicação do Trabalho Infantil e Proteção do Adolescente Trabalhador. Brasília, DF: Author.

Montaño, C., \& Duriguetto, M. L. (2011). Estado, classe e movimento social. São Paulo, SP: Cortez.

Movimento Nacional de Meninos e Meninas de Rua. (1994). Trajetória de luta em defesa da criança e do adolescente. São Paulo, SP: Author.

Nascimento, A. M., Ferrari, I., \& Martins, I. G. S., Filho. (2002). História do Trabalho, do Direito do Trabalho e da Justiça do Trabalho. São Paulo, SP: LTr.

Oliveira, P. A. F. (2006). Algumas curiosidades do modelo brasileiro de combate ao trabalho infantil. Inclusão Social, 1(2), 92-95. Retrieved from http://revista.ibict.br/inclusao/index.php/inclusao/article/view/42/67

Organização Internacional do Trabalho. (1999). International Programme on the elimination of child labour. Action against child labour: Strategies in education. Genebra: Author.

Organização Internacional do Trabalho. (2001). Combatendo o trabalho infantil: Guia para educadores. Retrieved from http://www.ilo.org/public/ portugue/region/ampro/brasilia/info/download/ guia/caderno.pdf

Organização Internacional do Trabalho. (2003). Atuação do Programa Internacional para a Eliminação do Trabalho Infantil (IPEC) no Brasil. In Organização Internacional do Trabalho, Boas práticas de combate ao trabalho infantil (pp. 3370). Brasília, DF: Author. Retrieved from http:// www.oit.org.br/node/323

Organização Internacional do Trabalho. (2010). Acelerar a ação contra o trabalho infantil. Retrieved from http://www.oit.org.br/node/386

Rizzini, I. (2008). O século perdido: Raízes históricas das políticas públicas para a infância no Brasil. São Paulo, SP: Cortez.

Rua, M. G. (2007). Avaliação da integração do Programa de Erradicação do Trabalho Infantil (PETI) ao Programa Bolsa Família (PBF). Brasília, DF: Fórum Nacional de Prevenção e Erradicação do Trabalho Infantil. 
Schwartzman, S. (2004). Tendências do trabalho infantil no Brasil entre 1992 e 2002. Brasília, DF: Organização Internacional do Trabalho.

Silva, M. O. S, Yaszbek, M. C., \& Di Giovanni, G. (2007). A politica brasileira no século XXI: Prevalência dos programas de transferência de renda. São Paulo, SP: Cortez.

Singer, P. (2010). A Cidadania para todos. In J. Pinsk \& C. B. Pinsky (Eds.), História da Cidadania (pp. 190-263). São Paulo, SP: Contexto.

Tonet, I. (2005). Educação, cidadania e emancipação humana. Ijuí, RS: Universidade Regional do Noroeste do Estado do Rio Grande do Sul.
Wacquant, L. (2001). As prisões da miséria. Rio de Janeiro, RJ: Jorge Zahar.

Yamamoto, O. H., \& Oliveira, I. F. (2010). Política Social e Psicologia: Uma trajetória de 25 anos [Special issue]. Psicologia: Teoria e Pesquisa, 26, 9-24. Retrieved from http://www.scielo. $\mathrm{br} /$ scielo.php? script $=$ sci arttext\&pid $=\mathrm{S} 0102$ $37722010000500002 \& \operatorname{lng}=$ pt\&nrm=iso $>$

Received: 18/03/2016

$1^{\text {st }}$ revision: $18 / 08 / 2016$

Accepted: 25/08/2016 